\title{
Familial Systemic Lupus Erythematosus Presence of a Cross-reactive Idiotype in Healthy Family Members
}

\author{
Roberta Halpern, Anne Davidson, Anne Lazo, Gary Solomon, Robert Lahita, and Betty Diamond \\ Departments of Microbiology and Immunology, and Medicine, Irvington House Institute for Medical Research, \\ Albert Einstein College of Medicine, Bronx, New York 10461
}

\begin{abstract}
Sera of 27 members of 3 human kindreds with familial systemic lupus erythematosus (SLE) were examined for expression of a cross-reactive idiotype present on anti-DNA antibodies of SLE patients.

By radioimmunoassay, serum samples from 6 of 8 SLE patients and 15 of 19 family members had high-titered reactivity with the antiidiotype, 3 I. Isoelectric focusing and Western blot analysis of 3I-reactive bands revealed two patterns of reactivity: either a pattern of bands present at pH 5-7, or bands present at pH 5-7 with additional bands present at pH 7-8.5. Cationic bands were found to correlate with the presence of anti-DNA antibodies, indicating that immunoglobulin charge may be a factor in determining specificity for DNA. Millipore filter analysis revealed anti-DNA antibodies in sera of 4 of 8 SLE patients and 2 of 19 family members without SLE. In 2 additional SLE patients and 2 additional family members, antiDNA antibodies were revealed when sera were analyzed under conditions that dissociate immune complexes.

This study indicates that expression of an idiotype associated with anti-DNA antibodies is significantly increased in relatives of SLE patients and usually occurs in the absence of antiDNA activity.
\end{abstract}

\section{Introduction}

The pathogenesis of systemic lupus erythematosus (SLE) ${ }^{1}$ appears to be multifactorial, including both hormonal and environmental influences (1). An important role for a genetic predisposition to SLE has been established by epidemiological analysis and studies of monozygotic twins (2). Patients with SLE demonstrate a significantly increased frequency of major histocompatibility complex antigens HLA-DR2, HLA-DR3, and MT1; however, studies of disease patterns in families with SLE suggest that additional genetic factors are involved. Thus, the molecular basis for the genetic susceptibility remains unclear (3).

Because SLE is a disease characterized by the production of autoantibodies, it is reasonable to ask whether the genetic predisposition might be related to the genes encoding these

Address reprint requests to Dr. Diamond, Department of Microbiology and Immunology, Albert Einstein College of Medicine, 1300 Morris Park Ave., Bronx, NY 10464.

Received for publication 22 February 1985.

1. Abbreviations used in this paper: SLE, systemic lupus erythematosus.

J. Clin. Invest.

(C) The American Society for Clinical Investigation, Inc.

0021-9738/85/08/0731/06 $\$ 1.00$

Volume 76, August 1985, 731-736 molecules. Recent studies demonstrate that the anti-DNA antibodies of unrelated SLE patients share cross-reactive idiotypes. The identification of shared structural features in antiDNA antibodies suggests that a restricted number of germ line genes may encode these autoantibodies $(4,5)$. We have previously described a monoclonal antibody, 3I, which recognizes a cross-reactive idiotype on anti-DNA antibodies (6). Hightitered 31 reactivity is found in over $85 \%$ of patients with SLE. While normal individuals do show low-titered expression of 3I-reactive antibodies, less than $1 \%$ of normal individuals have high titered expression. We describe here the use of this antiidiotype to examine the sera of members of three human kindreds with familial SLE to determine (a) whether idiotype expression can be correlated with the presence of anti-DNA antibodies and with disease, and $(b)$ whether isoelectric focusing gels of idiotypic antibodies reveal differences between idiotypic antibodies that have anti-DNA activity and those that do not.

\section{Methods}

Serum samples. Serum samples were obtained from SLE patients (defined by revised American Rheumatism Association criteria) (7) and their family members. Family 1 has two members with SLE; P.J. has renal involvement, E.U.J. does not. Clinical data on families 2 and 3 have previously been described (8). M.A.F. in family 2 had autoimmune thyroiditis, B.L. in family 3 had idiopathic thrombocytopenic purpura. Several family members have, on some occasion, had anti-nuclear antibodies in their serum. In this study sera were studied without respect to the clinical status of the patient. Normal sera were obtained from healthy volunteers; none of the volunteers were in contact with SLE patients or sera. All sera were heat-inactivated at $60^{\circ} \mathrm{C}$ for $30 \mathrm{~min}$. SLE patients and their family members were HLA typed by Dr. A. Gibofsky and Dr. R. Winchester and these data have been previously reported $(8,9)$.

Assays for $3 I$ reactivity. Sera were tested for reactivity with 31 by radioimmunoassay (6). Sera at a 1:1,000 dilution were plated in microtiter wells (Immulon 2; Dynatech Laboratories, Inc., Alexandria, VA) and reacted with 31 culture supernatant followed by $\left[{ }^{35}\right.$ S]methionine-labeled antibody to mouse kappa chains. Isoelectric focusing and Western blot transfer were performed. The nitrocellulose blots were incubated with 3I supernatant and 3I-reactive bands were revealed by peroxidase staining as previously described (10). Precipitates of DNA-anti-DNA antibodies were redissolved in $8 \mathrm{M}$ urea and similarly analyzed (see below).

Assays for anti-DNA activity. A modification of the Millipore filter method was used to detect anti-DNA reactivity (11). $2 \mu$ l of sera were diluted in $30 \mu \mathrm{l}$ of $0.02 \mathrm{M}$ phosphate-buffered saline (PBS; pH 7.2) and incubated at $37^{\circ} \mathrm{C}$ for $30 \mathrm{~min}$ with $2 \mu \mathrm{l}$ of ${ }^{32} \mathrm{P}$-labeled DNA (sp act, $10^{6} \mathrm{cpm} / \mu \mathrm{g}$ ) at a concentration of $2.5 \mu \mathrm{g} / \mathrm{ml}$. [ ${ }^{32} \mathrm{P}$ ]DNA was prepared by nick translation of plasmid DNA (12) and single-stranded DNA was removed by passing the labeled DNA through a Millipore filter (HAWP 24, Millipore Corp., Bedford, MA) immediately before use (11). The mixture of radiolabeled DNA and serum was passed through a Millipore filter and radioactivity bound to the filter was measured. Trapped radioactivity was considered abnormally high if it 
FAMILY 1

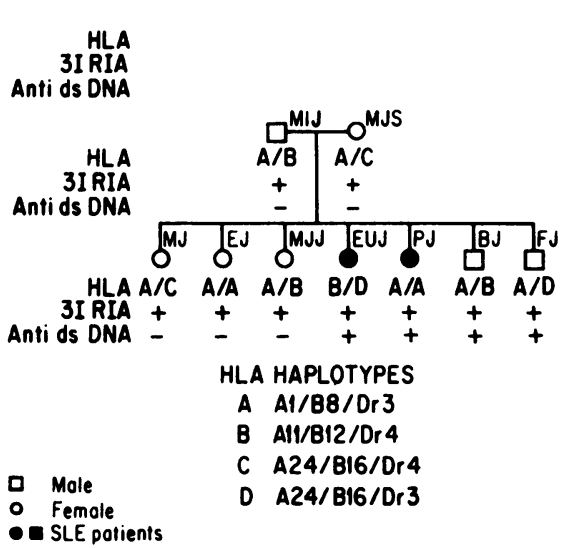

FAMILY 2

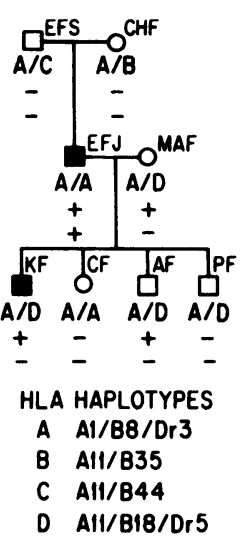

D All/B18/Dr 5 exceeded 2 SD above the mean of 10 normal volunteers. Isoelectric focusing of serum samples was performed as above. Electrophoretic transfer to nitrocellulose was performed in Tris buffer (Tris, $0.01 \mathrm{M}$; EDTA, $0.001 \mathrm{M} ; \mathrm{pH}$ 8.15). The filter was placed in Denhardt's solution for $45 \mathrm{~min}$ and then incubated with ${ }^{32}$ P-labeled DNA $\left(1 \times 10^{6} \mathrm{cpm}\right.$ diluted in $10 \mathrm{ml}$ of Denhardt's solution for $1 \mathrm{~h}$ ) at room temperature. Then, it was washed with Denhardt's solution, dried, and exposed to Kodak film XB-5 (Eastman Kodak Co., Rochester, NY) at $-70^{\circ} \mathrm{C}$ for $3 \mathrm{~h}$.

Isolation and characterization of precipitating antibodies. DNA anti-DNA precipitates were formed by reacting $50 \mu \mathrm{l}$ of serum with $200 \mu \mathrm{l}$ of calf thymus DNA $(150 \mu \mathrm{g} / \mathrm{ml})$ (Calbiochem-Behring Corp., La Jolla, CA) in $0.02 \mathrm{M}$ PBS. Mixtures were incubated at room temperature for $3 \mathrm{~h}$ and dialyzed against distilled water overnight. Precipitates were washed three times in distilled water and resuspended in $50 \mu \mathrm{l}$ PBS. The Ig class of the precipitating antibodies was determined by Ouchterlony analysis. For isoelectric focusing gels, $10 \mathrm{mg}$ urea was

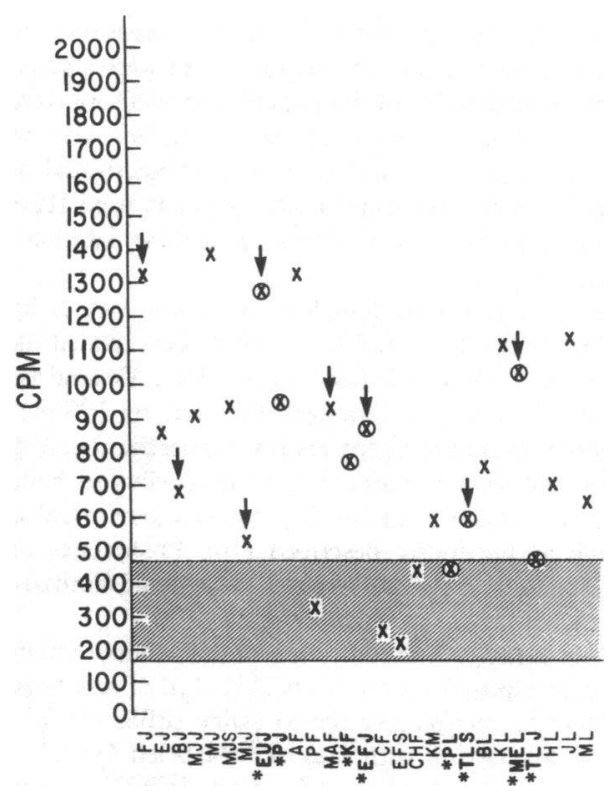

Figure 2. Mean 31 reactivity of serum from 20 normal subjects \pm 2 SD is indicated by the shaded area. 6 of 8 SLE patients (indicated by an asterisk) and 14 of 19 unaffected family members have 3I reactivity $>2$ SD above the mean of the controls. Values for SLE patients are enclosed in circles. Arrows identify those individuals with cationic 3I-reactive antibodies.
FAMILY 3

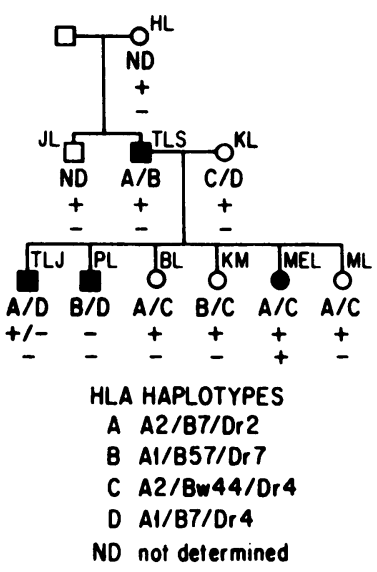

Figure 1. Genealogies for families 1, 2, and 3. There is no correlation between $3 I$ reactivity and HLA haplotype. added to $20 \mu \mathrm{l}$ of resuspended precipitate. Isoelectric focusing and Western blot transfer were performed as previously described (10). The nitrocellulose blot was blocked for 90 min with 3\% bovine serum albumin-saline, and then incubated with $2 \times 10^{7} \mathrm{cpm}$ of $\left.{ }^{35} \mathrm{~S}\right] \mathrm{me}-$ thionine-labeled 3I supernatant in $10 \mathrm{ml}$ for $90 \mathrm{~min}$ and exposed for $16 \mathrm{~h}$.

\section{Results}

Genealogies of the three families. In family 1 , the affected individuals are female; in family 2, male; and in family 3 , there are both males and a female with SLE. Of the patients with SLE, P.J., K.F., T.L.J., and P.L. have nephritis. The presence of anti-DNA antibodies and high-titer 3I reactivity did not appear to correlate with HLA-haplotype in any of the three families (Fig. 1). Only in family 1 are there unaffected individuals with anti-DNA activity detectable by Millipore filter assay. Interestingly, both these individuals are male, while the clinically affected members of the family are female.

$3 I$ reactivity. By radioimmunoassay, 6 of 8 patients with familial SLE and 15 of 19 family members without SLE had high-titered 3I reactivity (Fig. 2). One additional SLE patient, T.L.J., had borderline elevated $3 I$ reactivity. In each of the three families, there were unaffected individuals with hightitered idiotype expression. To determine if there was any difference between the 3I-reactive antibodies of SLE patients and those of unaffected family members, we displayed the serum samples on isoelectric focusing gels and analyzed the 3I-reactive antibodies on Western blots. This analysis revealed two patterns of 3I reactivity: in one, 3I-reactive bands were restricted to the $\mathrm{pH}$ range 5-7, and in the other, there were additional cationic 3I-reactive bands at pH 7-8.5 (Figs. 3, 4, and 5). SLE patients showed both patterns of reactivity. Patients P.J., K.F., P.L., and T.L.J. had 3I-reactive antibodies predominantly in the pH range 5-7; patients E.U.J., E.F.J., T.L.S., and M.E.L. had cationic 3I-reactive antibodies as well. Most unaffected family members showed only the first pattern whether high-titered 3I reactivity was present in their serum or not. However, four unaffected family members (B.J., F.J., M.I.J., and M.A.F.), all with high-titer 3I reactivity, had cationic 3I-positive antibodies present by Western blot analysis. While some of the individuals with cationic bands had very high-titer $3 \mathrm{I}$ reactivity (e.g., F.J. and E.U.J.), others had only moderate elevations in 3I reactivity (e.g., B.J. and T.L.S.). 


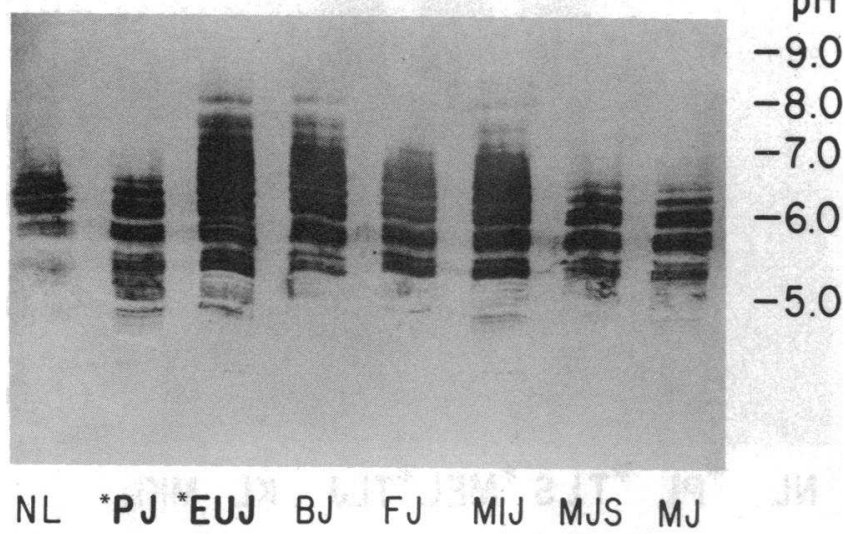

Figure 3. Western blot analysis of the binding of the 3I antiidiotype to serum samples from family 1 displayed on an isoelectric focusing gel. Lane NL, serum from a normal control. Lanes P.J. and E.U.J.; serum from SLE patients. Lanes B.J., F.J., M.I.J., M.J.S., and M.J.; serum from unaffected family members. E.U.J., B.J., F.J., and M.I.J. have 3I-reactive bands at $\mathrm{pH}>7$.

Cationic bands are therefore not merely a reflection of hightitered 3I reactivity. Family 3 had no unaffected individuals with cationic 3I reactive antibodies.

Anti-DNA activity. To determine whether 3I reactivity correlated with the presence of anti-DNA antibodies, we assayed all serum samples for DNA binding by the Millipore filter assay. The serum of four of the eight SLE patients, P.J., E.U.J., M.E.L., and E.F.J., all with elevated 3I reactivity, showed anti-DNA activity (Fig. 6). Among unaffected family members there were two, B.J. and F.J., both in family 1, who showed anti-DNA activity by Millipore filter assay. Both had high-titered 3 I reactivity as well.

We have previously found that patients who have hightitered 3I reactivity and no anti-DNA activity by Millipore filter assay may have masked anti-DNA antibodies that can be revealed by Western blot analysis performed under disso-

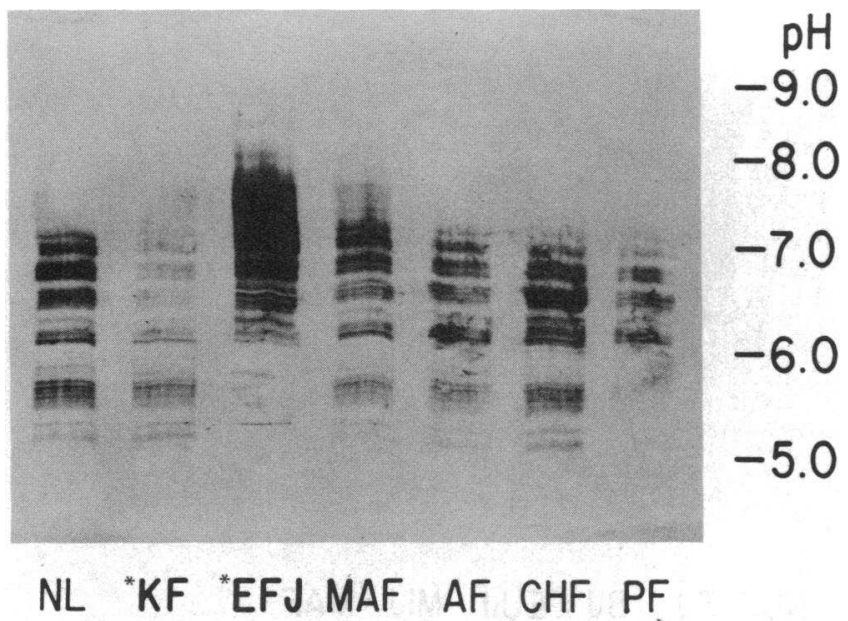

Figure 4. Western blot analysis of the binding of the 3I antiidiotype to serum samples from family 2 . Lane NL; serum from a normal control. Lanes K.F. and E.F.J.; serum from SLE patients. Lanes M.A.F., A.F., C.H.F., and P.F.; serum from unaffected family members. E.F.J. and M.A.F. have 3I-reactive bands at pH $>7$.

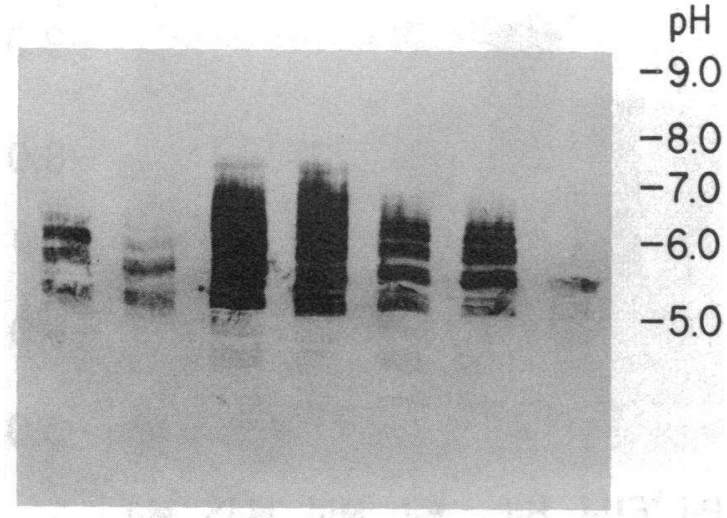

$\mathrm{NL}{ }^{*} \mathrm{PL}{ }^{*} \mathrm{TLS}{ }^{*} \mathrm{MEL}{ }^{*} \mathrm{TLJ} \quad \mathrm{KL} \quad \mathrm{MKL}$

Figure 5. Western blot analysis of the binding of the 31 antiidiotype to serum samples from family 3. Lane NL; serum from a normal control. Lanes P.L., T.L.S., M.E.L., and T.L.J.; serum from SLE patients. Lanes K.L. and M.K.L.; serum from unaffected family members. T.L.S. and M.E.L. have 3I-reactive bands at pH $>7$.

ciating conditions with radiolabeled DNA (10). To determine if SLE patients and unaffected family members with hightitered 3I reactivity and no anti-DNA activity by Millipore filter assay had masked anti-DNA antibodies, we subjected all serum samples to this type of analysis (Figs. 7, 8, and 9). All serum samples positive for DNA binding by Millipore filter assay were also reactive by Western blot analysis. The Western blots indicated that two of the SLE patients, T.L.S. and T.L.J., who were negative on Millipore filter assay had masked antiDNA antibodies (Fig. 9). Both of these are in family 3. Two unaffected family members, M.I.J. from family 1 and M.A.F. from family 2 , who had high-titered $3 \mathrm{I}$ reactivity but no antiDNA antibodies by Millipore filter assay, also had masked

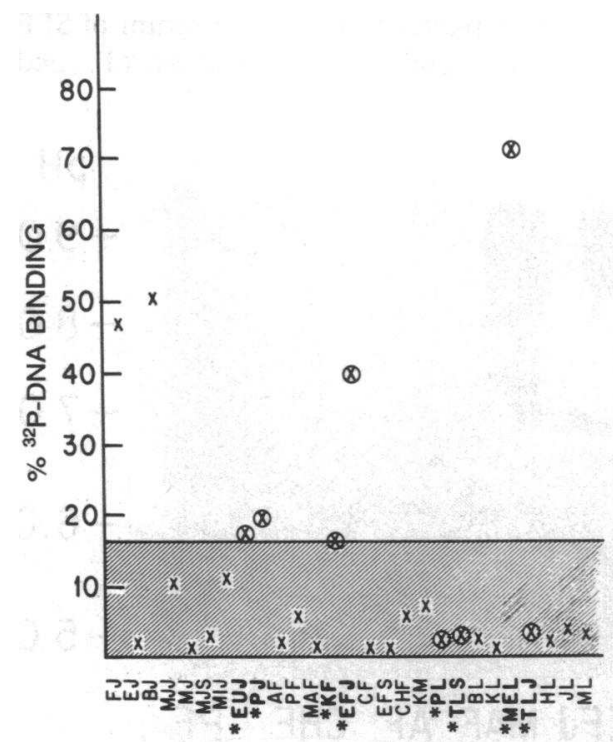

Figure 6. Anti-DNA activity was measured by Millipore filter assay. The shaded area represents the mean binding of 10 normal control sera \pm 2 SD. 4 of 8 SLE patients (indicated by an asterisk) and 2 of 19 unaffected family members had anti-DNA activity. Values for SLE patients are enclosed in circles. 


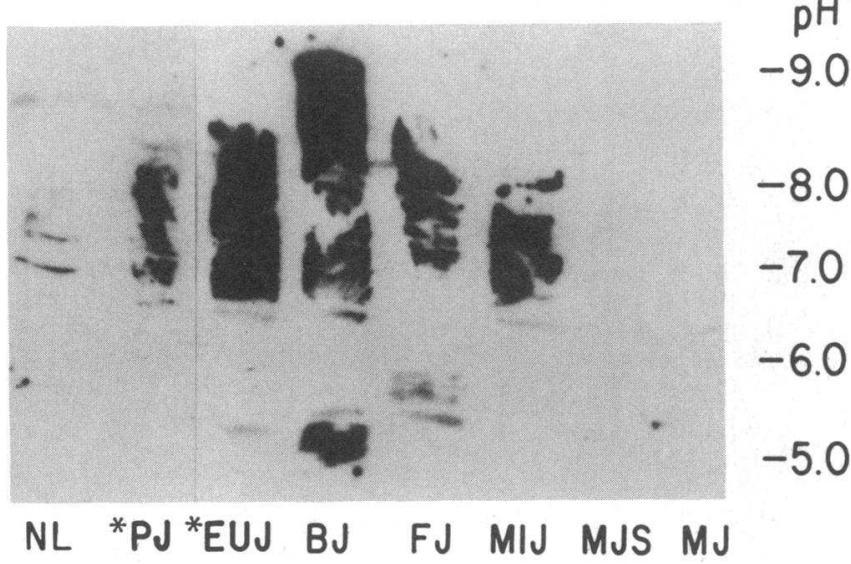

Figure 7. Western blot analysis of the binding of radiolabeled DNA to isoelectrically focused serum samples from family 1 . Lane NL; serum from a normal control. Lanes P.J. and E.U.J.; serum from SLE patients. Lanes B.J., F.J., M.I.J., M.J.S., and M.J.; serum from unaffected family members. P.J., E.U.J., B.J., F.J., and M.I.J. show DNA-binding immunoglobulins.

anti-DNA antibodies, which are revealed by Western blot analysis (Figs. 7 and 8). However, the other 11 family members with high-titered 3 I reactivity failed to reveal anti-DNA antibodies present either in free or in masked form. Only the unaffected family members with anti-DNA antibodies, free or masked, had cationic 3I-reactive bands (F.J., B.J., and M.I.J. from family 1 in Figs. 3 and 7; M.A.F. from family 2 in Figs. 4 and 8 ), suggesting that the acquisition of DNA reactivity may be associated with a difference in charge.

DNA-anti DNA precipitates. The sera of SLE patient E.U.J., the four unaffected family members with anti-DNA antibodies (F.J., B.J., M.I.J., and M.A.F.), and one normal individual were tested to see which sera formed precipitates with DNA in vitro, a finding thought to be correlated with pathogenicity (13). Precipitating anti-DNA antibodies were found for all but the normal serum. Ouchterlony analysis revealed predominantly IgG antibodies in the precipitates formed from serum of SLE patient E.U.J. and family members M.I.J. and M.A.F., and
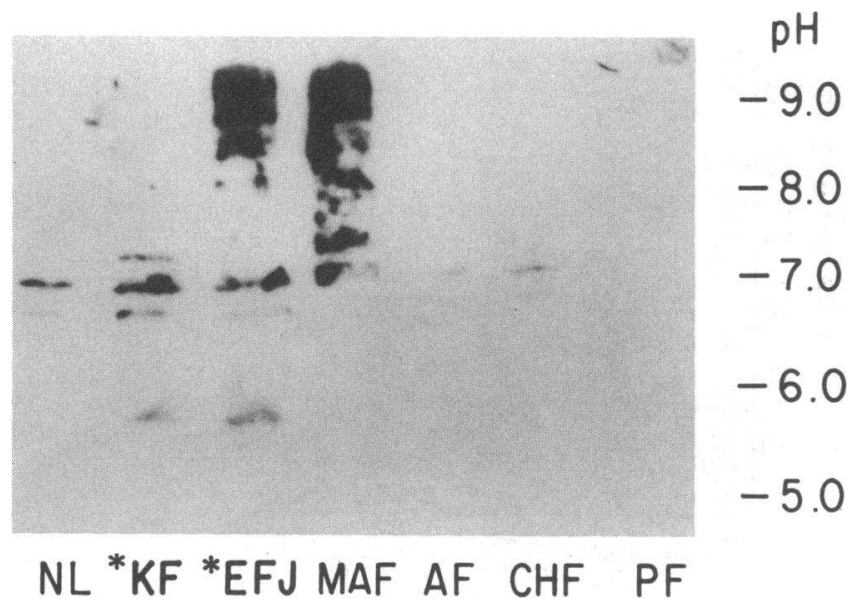

Figure 8. Western blot analysis of the binding of radiolabeled DNA to serum samples from family 2. Lane NL; serum from a normal control. Lanes K.F. and E.F.J.; serum from SLE patients. Lanes M.A.F., A.F., C.H.F., and P.F.; serum from unaffected family members. E.F.J. and M.A.F. show DNA-binding immunoglobulins.

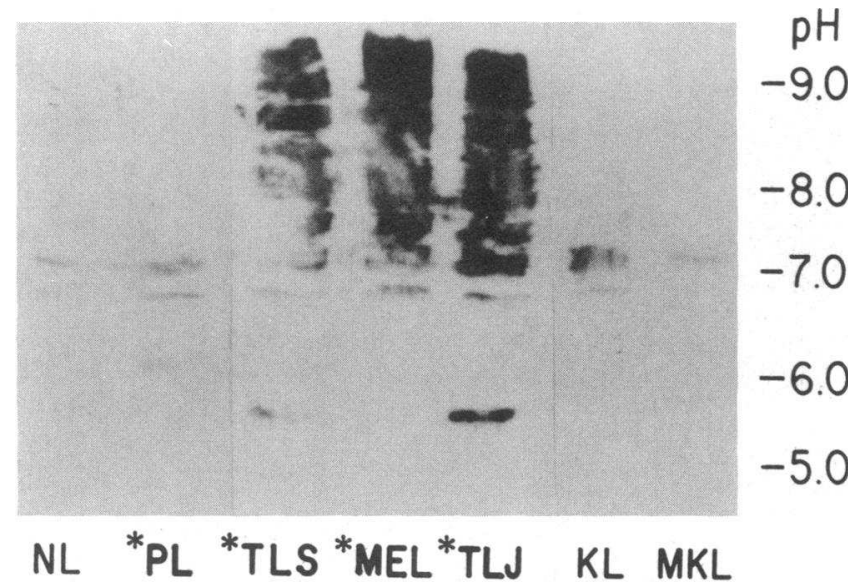

Figure 9. Western blot analysis of the binding of radiolabeled DNA to serum samples from family 3. Lane NL; serum from a normal control. Lanes P.L., T.L.S., M.E.L., and T.L.J.; serum from SLE patients. Lanes K.L. and M.K.L.; serum from unaffected family members. T.L.S., M.E.L., and T.L.J. show DNA-binding immunoglobulins.

both IgG and IgM antibodies in the precipitates formed from F.J. and B.J. serum. The DNA anti-DNA precipitates were tested for 3 I reactivity on Western blots of isoelectric focusing gels and all were found to include 3I-reactive anti-DNA antibodies (Fig. 10). The isoelectric focusing gels of serum 3Ireactive antibodies revealed antibodies which focus from $\mathrm{pH}$ 5 to $\mathrm{pH} 8.75$. The precipitating antibodies focus from $\mathrm{pH} 6.75$ to $\mathrm{pH} 8.75$, suggesting again that the 3I-reactive antibodies that bind DNA are cationic.

\section{Discussion}

The variable region of each immunoglobulin molecule is characterized by a constellation of antigenic determinants that are, in composite, the idiotype of the molecule. Immunoglobulin molecules which share a number of these determinants are said to have a cross-reactive idiotype. Analysis of anti-DNA antibodies from inbred strains of mice that develop a lupus- 
like syndrome has revealed the existence of such cross-reactive idiotypes (14-16). More surprisingly, analysis of anti-DNA antibodies from unrelated patients with SLE has likewise revealed the existence of cross-reactive idiotypes. Cross-reactive idiotypes occur also on anti-acetylcholine receptor antibodies in myasthenia gravis (17), antithyroglobulin antibodies in autoimmune thyroiditis (18), and anti-RO/SSA antibodies in families with complement (C2) deficiency (19), suggesting that a restricted number of germ line genes encode the pathogenic antibodies in many autoimmune diseases.

We have previously reported a monoclonal antiidiotype, 3I, which recognizes a cross-reactive idiotype on human antiDNA antibodies in a majority of patients with SLE (6). This idiotype is expressed in low titer in normal individuals and in high titer in SLE patients. Because the 3I anti-idiotype is not directed to the DNA-binding site, it is able to detect anti-DNA antibodies in lupus serum which are masked in conventional antigen-binding assays, presumably either by excess antigen or by autologous antiidiotype.

In the present study we have examined the expression of this cross-reactive idiotype in kindreds with familial lupus. We have found that family members without SLE have hightitered idiotype expression, and that cationic idiotypic antibodies have increased affinity for DNA. 6 of 8 SLE patients and 15 of 19 family members have elevated expression of the 3I idiotype; one additional SLE patient has borderline elevated reactivity. Those sera with elevated 3 I reactivity but no antiDNA antibodies have 3I-reactive bands focusing at pH 5-7. Cationic 3I-reactive antibodies were found only in sera with anti-DNA antibodies, whether from SLE patients or from clinically unaffected family members. Thus the cationic charge of 3I-reactive immunoglobulin appears to be associated with increased affinity for DNA. We do not know if this is the case for all anti-DNA antibodies but it appears to be so for 3Ireactive anti-DNA antibodies. While there are anti-DNA antibodies that are not cationic and 3I-reactive antibodies that are not cationic, the 3I-reactive antibodies that precipitate with DNA almost all focus at $\mathrm{pH}>7$ (Fig. 10). It has been suggested that cationic anti-DNA antibodies are preferentially deposited in the kidney, perhaps because they bind to polyanionic sites in glomerular basement membrane (20). Our data suggest that cationic anti-DNA antibodies may be more pathogenic also because of increased affinity for DNA.

In 1 SLE patient and 11 relatives, high-titered 3I reactivity was not associated with anti-DNA antibodies, masked or unmasked. In these sera there were no cationic 3I-reactive antibodies. In this study we report single serum samples, and it is possible that both the SLE patients and some of the family members may have anti-DNA antibodies present at other times as many of them intermittently have anti-nuclear antibodies. However, it is clear from this study that idiotype expression can be dissociated from DNA-binding activity.

In our study, four family members without SLE were found to have anti-DNA antibodies; one of these, M.A.F., had a history of autoimmune thyroiditis. Two were very high titer by conventional anti-DNA assay and two were unmasked by analysis under dissociating conditions. They all had precipitating antibodies of the IgG class which were cationic on isoelectric focusing gels, characteristics which have been reported to correlate with increased antibody pathogenicity. Therefore, the relationship between autoreactive antibodies and autoimmune disease remains to be defined. It is rare to find anti-DNA antibodies present in normal individuals; however, the presence of anti-DNA antibodies in healthy relatives, both blood related and nonblood related, of patients with SLE has been reported (21). Whether these individuals without SLE chronically have anti-DNA antibodies present in their serum and whether they will go on to develop overt disease is a matter of great interest.

It is of interest that, in our study, some spouses (M.A.F. and K.L.) had high-titered reactivity with the 3I antiidiotypic antibody. M.A.F. had cationic 3I-reactive antibodies and antiDNA activity. K.L. had 3I-reactive antibodies focusing at pH $<7$ and no anti-DNA activity. It is not known if they exhibited elevated expression of the 3I idiotype before their cohabitation with SLE patients or if they acquired high-titered 3I reactivity thereafter. It is possible that both spouses are exposed to a common environmental antigen and respond by producing 3I-reactive antibodies. Alternatively, the fact that both spouses have high-titered 3 I reactivity need not reflect a common exposure to antigen but merely a coincidentally shared genetic predisposition to utilize particular germ line genes. In this context we note that M.A.F. has an unrelated autoimmune disease, Hashimoto's thyroiditis. We do not know whether the expression of $3 I$ is increased in this disease. Inheritance from both parents of the predisposition to express this idiotype may markedly increase one's chance of developing SLE.

Some similar observations have been made by investigators studying other autoimmune diseases. A dissociation of idiotype expression and antigenic reactivity has been reported by Qian et al. (19), who observed high titers of the cross-reactive idiotype found on anti-RO/SSA autoantibodies in healthy members of two C2-deficient families who had no anti RO/ SSA activity. Lefvert et al. (22) have analyzed sera from family members of patients with myasthenia gravis using an antiidiotype to anti-acetyl choline receptor antibodies. Several unaffected family members showed high expression of the idiotype. Additionally some family members have anti-acetyl choline receptor antibodies. Similarly Pasquali et al. (23) demonstrated the presence of an idiotype found on IgM rheumatoid factor from a patient with classical rheumatoid arthritis in four first degree relatives, only two of whom had rheumatoid arthritis. There was no association between inheritance of idiotype and HLA haplotype in this family. A study of peripheral blood B cells of patients with rheumatoid arthritis has shown that although there are many B cells present that are bound by an antiserum to a rheumatoid factor cross-reactive idiotype, not all these B cells have rheumatoid factor activity (24). Idiotypepositive antigen-binding immunoglobulin and idiotype-positive nonantigen-binding immunoglobulin are both present in the same patient. Thus family members of patients with autoimmune diseases may have high expression of antibodies bearing the idiotype of the pathogenic autoantibody without showing autoantibody activity. Even in patients with autoantibodies, there are some idiotypic antibodies without autoantibody activity. Finally there are some individuals with autoantibody activity and yet no disease.

The antigenic specificity of 3I-reactive antibodies in the serum of healthy individuals is not known. A possible interpretation is that 3I-reactive antibodies are made in response to some unknown antigen and that these antibodies subsequently mutate and acquire reactivity with DNA. It has, in fact, been suggested that bacterial antigens rather than DNA itself may elicit production of anti-DNA antibodies (25). We have previously shown that a murine monoclonal anti-phosphorylcholine antibody which has undergone a glutamic acid to alanine substitution in a heavy chain hypervariable region 
loses affinity for phosphorylcholine and acquires reactivity with DNA and other phosphorylated macromolecules (26). While it is possible that different germ line genes encode 3Ireactive DNA-binding and 3I-reactive non-DNA-binding antibodies or that the 3I-reactive chain is linked to a different heavy chain in each case, it may be that somatic mutation converts a 3I-positive non-DNA-binding immunoglobulin into a 3I-positive anti-DNA antibody. If this occurs, our data suggests that this may be associated with a change in charge such that the DNA-binding 3I-reactive antibody becomes more cationic.

That a genetic predisposition towards development of SLE exists is now well established. In previous studies of SLE, disease has been associated with HLA haplotype. In this study there was no association of HLA haplotype with either disease or idiotype expression, a finding similar to that of Pasquali et al. (23). It is interesting to speculate, on the basis of the data reported here, that the genetic predisposition to SLE may reflect, in part, the use of particular immunoglobulin variable regions, such as the one encoding 3I-reactive immunoglobulins, used to make antibodies against bacteria or other commonly encountered antigens. Regulation of expression of the 3I idiotype may be under genetic control. Those with high-titered 3I reactivity may express more of this idiotype in response to microbial antigens. Randomly occurring somatic mutations may then convert 3I-positive non-DNA-binding antibodies into idiotype-positive anti-DNA antibodies. These mutations may be associated with a change in charge of the idiotypepositive immunoglobulins. Some variable regions used in making anti-bacterial antibodies may require a larger number of mutations to become anti-DNA antibodies, while others, such as 3I-reactive antibodies, may be only a few mutations away from autoreactivity and therefore be more likely to form autoantibodies. Individuals with high-titered 3I reactivity may thus be more likely to develop 3I-reactive anti-DNA antibodies than individuals without high-titered $3 \mathrm{I}$ reactivity.

\section{Acknowledgments}

We would like to thank Donna Jackson and Laurie Vitagliano for preparing the manuscript.

Dr. Diamond is an Established Fellow of the American Heart Association. Dr. Davidson is supported in part by a grant from The Royal Australian College of Physicians. This work was supported by National Institutes of Health grants AM 32371, AI10702, and AM 04761; National Cancer Institute grant 3POCA1330; and a grant from the SLE Foundation.

\section{References}

1. Arnett, F. C., J. D. Reveille, R. W. Wilson, T. T. Provost, and W. B. Bids. 1984. Systemic lupus erythematosus: current state of the genetic hypothesis. Semin. Arthritis Rheum. 14:24-35.

2. Block, S. R., J. B. Winfield, M. D. Lockshin, W. A. D'Angelo, and C. L. Christian. 1975. Studies of twins with systemic lupus erythematosus: a review of the literature and presentation of 12 additional sets. Am. J. Med. 59:533-552.

3. Ahearn, J. M., T. T. Provost, C. A. Dorsch, M. B. Stevens, W. B. Bias, and F. C. Arnett. 1982. The interrelationships of HLADR, MB, and MT phenotypes, autoantibody expression, and clinical features in systemic lupus erythematosus. Arthritis Rheum. 25:10311040.

4. Zouali, M., and A. Eyquem. 1984. Idiotype restriction in human autoantibodies to DNA in systemic lupus erythematosus. Immunol. Lett. 7:187-190.

5. Shoenfeld, Y., D. A. Isenberg, J. Rauch, M. P. Madaio, D. Stollar, and R. S. Schwartz. 1983. Idiotypic cross-reactions of monoclonal human lupus autoantibodies. J. Exp. Med. 158:718-730.
6. Solomon, G., J. Schiffenbauer, H. D. Keiser, and B. Diamond. 1983. Use of monoclonal antibodies to identify shared idiotypes on human antibodies to native DNA from patients with systemic lupus erythematosus. Proc. Natl. Acad. Sci. USA. 80:850-854.

7. Tan, E. M., A. S. Cohen, J. F. Fries, A. T. Masi, D. J. McShane, N. F. Rothfield, J. G. Schaller, N. Talal, and R. J. Winchester. 1982. Revised criteria for the classification of systemic lupus erythematosus. Arthritis Rheum. 25:1271-1277.

8. Lahita, R. G., N. Chiorazzi, A. Gibofsky, R. J. Winchester, and H. G. Kunkel. 1983. Familial systemic lupus erythematosus in males. Arthritis Rheum. 26:39-44.

9. Winchester, R. J., and H. G. Kunkel. 1979. The human Ia system. Adv. Immunol. 28:221-292.

10. Halpern, R., J. Schiffenbauer, G. Solomon, and B. Diamond. 1984. Detection of masked anti-DNA antibodies in lupus sera by a monoclonal anti-idiotype. J. Immunol. 133:1852-1856.

11. Ginsberg, B., and H. Keiser. 1973. A Millipore filter assay for antibodies to native DNA in sera of patients with systemic lupus erythematosus. Arthritis Rheum. 16:199-207.

12. Rigby, P. W. J., M. Dieckman, C. Rhodes, and P. Berg. 1977. Labelling deoxyribonucleic acid to high specific activity in vitro by nick translation with DNA polymerase. I. J. Mol. Biol. 113:237-251.

13. Gershwin, E. M., and A. D. Steinberg. 1974. Quantitative characteristics of anti-DNA antibodies in lupus nephritis. Arthritis Rheum. 17:947-954.

14. Rauch, J., E. Murphy, J. B. Roths, B. D. Stollar, and R. S. Schwartz. 1982. A high frequency idiotypic marker of anti-DNA autoantibodies in MRI-Ipr/Ipr mice. J. Immunol. 129:236-241.

15. Marion, T. N., A. R. Lawton, J. F. Kearney, and D. Briles. 1982. Anti-DNA autoantibodies in (NZB $\times N Z W) F_{1}$ mice are clonally heterogeneous, but the majority share a common idiotype. J. Immunol. 128:668-674.

16. Hahn, B. H., and F. M. Ebling. 1984. A public idiotypic determinant is present on spontaneous cationic IgG antibodies to DNA from mice of unrelated lupus-prone strains. J. Immunol. 133: 3015-3019.

17. Dwyer, D. S., R. J. Bradley, C. K. Urquhart, and J. F. Kearney. 1983. Naturally occurring anti-idiotypic antibodies in myasthenia gravis patients. Nature (Lond.). 301:611-614.

18. Zanetti, M., J. Rogers, and D. H. Katz. 1984. Induction of autoantibodies to thyroglobulin by anti-idiotypic antibodies. J. Immunol. 133:240-243.

19. Qian, G., S. M. Fu, and M. Reichlin. 1984. Cross reactive idiotype of anti RO/SSA antibodies: identification of a $\mathrm{V}$ region marker preferentially expressed in SLE. Arthritis Rheum. 27:S16. (Abstr.)

20. Ebling, F., and B. H. Hahn. 1980. Restricted subpopulations of DNA antibodies in kidneys of mice with systemic lupus: comparison of antibodies in serum and renal eluates. Arthritis Rheum. 23:392402.

21. Folomeeva, O., V. A. Nassonova, A. S. Alekberova, N. Talal, and R. C. Williams, Sr. 1978. Comparative studies of antilymphocyte, antipolynucleotide and antiviral antibodies among families of patients with systemic lupus erythematosus. Arthritis Rheum. 21:23-27.

22. Lefvert, A. K., R. Pirskanen, and E. Svanborg. 1985. Antiidiotypic antibodies, acetylcholine receptor antibodies and disturbed neuromuscular function in healthy relatives to patients with myasthenia gravis. J. Neuroimmunol. In press.

23. Pasquali, S. L., S. Fong, C. Tsoukas, S. H. Vaughan, and D. A. Carson. 1980. Inheritance of immunoglobulin $M$ rheumatoid factor idiotypes. J. Clin. Invest. 66:863-866.

24. Bonagura, V. R., H. G. Kunkel, and B. Pernis. 1982. Cellular localization of rheumatoid factor idiotypes. J. Clin. Invest. 69:13561365 .

25. Schwartz, R. S. 1983. Lessons about autoimmunity from hybridomas. In Progress in Immunology V: Fifth International Congress of Immunology. Y. Yamamura and T. Tada, editors. Academic Press, Orlando, FL. 1111-1114.

26. Diamond, B., and M. D. Scharff. 1984. Somatic mutation of the T15 heavy chain gives rise to an antibody with autoantibody specificity. Proc. Natl. Acad. Sci. USA. 81:5841-5844. 